\title{
THE MOST IMPORTANT FACTORS THAT DETERMINE TURNOVER INTENTION
}

\author{
Susilawati Ni Kadek*, Commissioner and Director of Finance \\ PT. Karya Trustindoutama, Indonesia
}

Darma Gede Sri, Professor and Director

Undiknas Graduate School, Indonesia

*E-mail: kadeksusilawati@gmail.com

\begin{abstract}
The purpose of this study was to find out work family conflict and work overload mediating the effect of role stress and role ambiguity on turnover intention of employees of PT Karya Trustindoutama Denpasar. The samples taken were 76 employees. The analysis technique used is SEM partial least square (PLS) analysis. The results of the analysis show that role stress has a positive and significant influence on turnover intention. Stress has a positive and significant influence on work family conflict. Stress has a positive and significant effect on work overload. Ambiguity has a positive and significant effect on turnover intention. Ambiguity has a positive and significant effect on work family conflict. Ambiguity has a positive and significant effect on work overload. Work family conflict has a positive and significant influence on turnover intention. Work overload has a positive and significant effect on turnover intention. Work family conflict has a significant positive effect as a variable capable of mediating role stress and role ambiguity towards turnover intention. Work overload has a significant positive effect as a variable capable of mediating role stress and role ambiguity towards turnover intention.
\end{abstract}

\section{KEY WORDS}

Role stress, role ambiguity, work family conflict, work overload, turnover intention.

Changes in the economic field encourage organizations to improve themselves in the face of existing competition. Correcting a company can be done by preparing a workforce that is resilient and skilled so that good work performance is achieved which will increase company productivity. HR is always attached to every organization's resources within the company, one of which is a company providing employment services as a determining factor for its existence and role in contributing towards achieving organizational goals effectively and efficiently (Febrianty, 2012).

In our various daily activities are often helped and even dependent on services. This shows that service business is very influential in this modern world (Sarah et al., 2015). Some examples of business in the service sector include labor service providers, banking services, consulting services etc. The progress of the global economy, growth in the service sector is increasing. Turnover intention behavior is basically the same as the desire to move employees from one workplace to another. "The opinion shows that turnover intentions are the desire to move, not yet at the realization stage, namely move from one work place to another. Employee turnover results in several losses for the company, such as costs to be borne and time spent on recruitment, selection and training in order to get employees who are of the same quality as those leaving the company (Rajan et al., 2016).

PT Karya Trustindoutama, is a company engaged in the business of managing labor that is ready to meet the needs of human resources for the company. Looking at the results of several previous studies and seen from the existing real conditions, it can be seen that role stress, role ambiguity, work family conflict and work overload affect employee turnover intention. Therefore, this study wants to find out how much influence on the employees of PT Karya Trustindoutama Denpasar with the current system. 


\section{LITERATURE REVIEW}

Kreitner and Kinicki (2008: 351) define role stress as an adaptive response connected by individual characteristics and or psychological processes, which is a consequence of any external actions, situations, or events that place specific psychological / physical demands on a person. Moekijat (2010: 28) states that role stress is a feeling of pressure or feeling depressed experienced by employees in the face of work, work stress can cause unstable emotions, feelings of uneasiness, like to be alone, difficulty sleeping, excessive smoking, unable to relax, anxiety, tension, nervousness, increased blood pressure and indigestion. According to Kreitner and Kinicki (2008: 79) indicators of variables relating to work stress include work beyond the limits of ability, frequent delays in work, absence from work, difficulty making decisions, careless mistakes.

Role ambiguity is the gap between the amount of information a person has and what he needs to be able to carry out his role appropriately. Therefore, the ambiguity of the role is stressful because it prevents the individual from doing his job and causes feelings of insecurity and uncertainty. Unclear roles according to Nurnazirah et al. (2015) relates to two things, namely (1) Predictability of results or responses to a person's behavior, and (2) The existence or clarity of the required behavior that will guide the behavior and provide information that the behavior is appropriate.

Newstrom (2011: 94) states that a person can be said to be in a blurring of roles if he shows the characteristics, among others, as follows, it is not clear what the purpose of the role he plays, it is unclear to whom he is responsible and who reports to him, not fully understanding what expected from him, do not understand the true role of the work in the context of achieving overall goals (Brief et al. in Nimran, 1999: 86).

Marquise and Huston (in Nurnazirah et al, 2015) define conflict as internal and external problems that occur as a result of differences of opinion, values, beliefs of two people or more. According to Littlefield (in Eka, 2014) that conflict can be categorized as an event or process. As an incident, a conflict occurs from a disagreement between two people or organizations, where the person accepts something that will threaten their interests. Jendra and Riana (2015) stated that as a process, conflict is manifested as a series of actions taken by two or more groups trying to obstruct or prevent satisfaction from someone.

According to Greenhaus and Beutell (in Nurnazirah et al, 2015) there are three kinds of dual role conflict, namely time-based conflict, strain-based conflict, behavior based conflict.

Luthans (2011: 82) defines workload or work overload is a term that began to be known around 1970. Many experts have put forward the definition of workload so that there are several different definitions of workload. It is a multi-dimensional concept, so it is difficult to get just one conclusion about the right definition (Yang, 2015). Mansaour (2015) defines workload as the difference between the ability of employees with the demands of the task received. The workload can be in the form of physical workload and mental workload.

Mansaour et al. (2015) divides physical and mental workloads into six dimensions, physical workload measures including physical demand, and effort. Mental workload measures include mental demand, temporal demand, performance and frustration levels, namely physical demand, effort, mental demand, temporal demand, frustation level performance.

Resignation of employees or return intention can be interpreted as the movement of workers out of the organization. Turnover according to Robbins and Judge (2008: 38) is an act of permanent resignation carried out by employees either voluntarily or not voluntarily. Turnover can be in the form of resignation, movement out of organizational units, dismissal or death of members of the organization. Gorda (2006: 96) states that the occurrence of employee turnover is something that is not desired by the company while on the other hand employee turnover is a classic problem that has been faced by employers since the era of industrial evolution.

From the definitions of the two experts above, it can be concluded that employee turnover intentions that occur are detrimental to the company in terms of cost, resources and service quality which will ultimately lead to customer satisfaction. 
Robbins (2011: 181-182) states that the indicators that influence turnover are complex and interrelated. Among the indicators that will be discussed include age, length of work, level of education and intelligence, attachment to the company.

Hypotheses:

- $\mathrm{H} 1$ : The higher the role stresses the more employee turnover intention increases;

- H2: The higher the role stress, the more work family conflict increases;

- H3: The higher the role stress, the more work overload will increase;

- H4: The higher the role of ambiguity, the more employee turnover intention will increase;

- H5: The higher the role of ambiguity, the more work family conflict the employee increases;

- H6: The higher the role of ambiguity, the more work overload of employees is;

- H7: The higher work family conflict, the more employee turnover intention increases;

- H8: The higher the work overload, the more employee turnover intention will increase;

- H9: The higher work family conflict will mediate the role of stress and role ambiguity towards employee turnover intention;

- H10: The higher work overload will mediate the role of stress and role ambiguity towards employee turnover intention.

\section{METHODS OF RESEARCH}

The population in this study were employees who worked at PT Karya Trustindoutama Denpasar. The population in this study amounted to 320 employees. According to Arikunto (2013: 174) said that the sample is as or representative of the population under study. Furthermore according to Sugiyono (2014: 14) the sample is part of the number and characteristics possessed by the population. The research sample is a portion of the population that can represent the population, from 320 employees will be sought proportional sample so that it can represent the population using the Slovin formula (in Umar, 2007) Samples that can still be tolerated or desired. The error limits that can be used are from 1$10 \%$. The population used in this study was 320 employees, using an error limit of $10 \%$. The large number of employee samples obtained was 76 people. The sample to be used is based on the proportionate random sampling method because members of the population are homogeneous so that it can represent the entire population. Data analysis used in this study is the CB-SEM (Covariance Based-Structural Equation Modeling) with the AMOS (Analysis of Moment Structure) program. According to Ferdinand (2014: 45), SEM is a combination of two separate statistical methods, namely to confirm indicators of a latent and structural variable that describes the causal relationship between two or more variables.

\section{RESULTS OF STUDY}

Based on the results of the analysis shows that role stress has a positive and significant effect on employee turnover intention at PT Karya Trustindo Utama Denpasar. This means that the higher the level of stress experienced by employees will make the turnover intention more. Based on this, the role stress hypothesis has a positive effect on turnover intention. These results are consistent with research conducted by Jendra and Riana (2015) showing that role stress has a significant positive relationship on employee turnover intention. Muhammad (2017) states that employee turnover intention is positively influenced by the role stress experienced by employees. Rahmat (2016) states that work stress has a positive and significant effect on work family conflict. Tajmal (2015) work stress has a positive and significant effect on turnover intentions.

Based on the results of the analysis shows that role stress has a positive and significant effect on work family conflict among employees at PT Karya Trustindo Utama Denpasar. This means that the higher the level of stress experienced by employees, the 
higher the work family conflict experienced by employees. Based on this, the role stress hypothesis has a positive effect on work family conflict can be accepted.

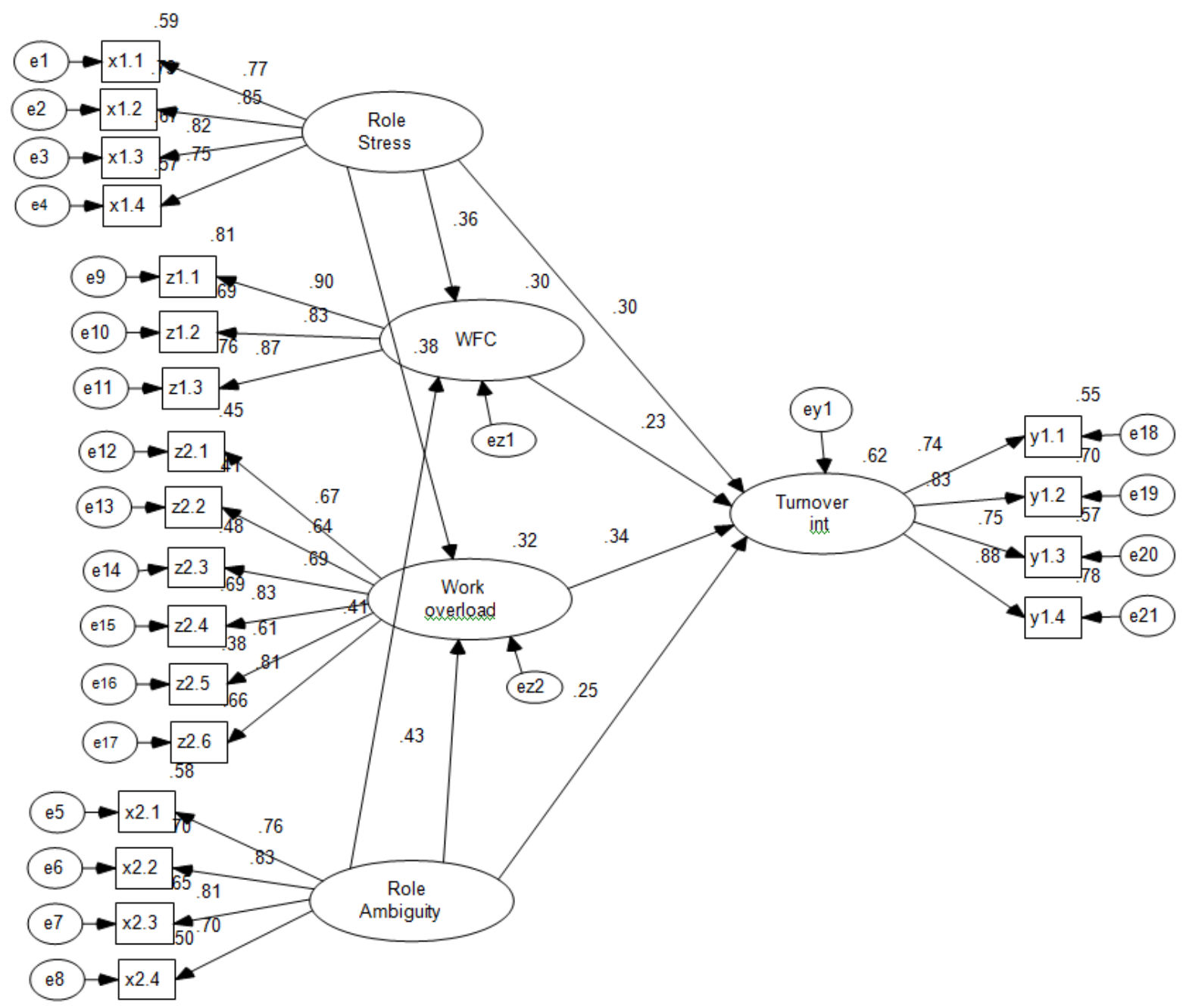

Figure 1 - Bootstrapping (Statistical Test) Research Variables

The results of this study are consistent with several results such as Veliana et al. (2017) shows that role stress has a significant positive relationship on employee family work conflicts. Rahmat et al. (2016) states that the attitude of work family conflict is positively influenced by the role stress experienced by employees. Jendra and Riana (2015) stated that role stress has a significant positive relationship on employee family work conflicts. Muhdiyanto (2018) states that the attitude of work family conflict is positively influenced by the role stress experienced by employees.

Based on the results of the analysis shows that role stress has a positive and significant effect on work overload for employees at PT Karya Trustindo Utama Denpasar. This means that the higher the level of stress experienced by employees will make the more work overload felt by employees. Based on this, the role stress hypothesis has a positive effect on work overload.

These results are consistent with research conducted by Tajmal (2015) showing that role stress has a significant positive relationship on work overload experienced by employees. Andika and Imam (2015) stated that the work overload experienced by employees is positively influenced by the employee's role stress. Atika et al. (2016) role stress has a significant positive effect on work overload experienced by employees. Veliana and Jesslyn (2017) role stress variables have a positive effect on increasing work overload felt by employees. 
Based on the results of the analysis shows that role ambiguity has a positive and significant effect on turnover intention on employees at PT Karya Trustindo Utama Denpasar. This means that the higher the level of role ambiguity experienced by employees, the stronger the desire of employees to make turnover intentions. Based on this, the role ambiguity hypothesis has a positive effect on turnover intention.

These results are consistent with research conducted by Muhdiyanto and Muji (2018) finding that there is a significant relationship between role ambiguity and turnover intention. Shaini (2017) states that the results of the partial correlation analysis show that role ambiguity is positively correlated with turnover intention. Tajmal (2015) states the role ambiguity variable has a positive influence on turnover intention. Jasmani et al. (2015) in his research proved that the role ambiguity variable has a positive influence on turnover intention.

Based on the results of the analysis shows that role ambiguity has a positive and significant effect on work family conflict among employees at PT Karya Trustindo Utama Denpasar. This means that the higher the level of role ambiguity experienced by employees, the more work family conflicts that employees feel. Based on this, the role ambiguity hypothesis has a positive effect on work family conflict.

These results are consistent with research conducted by Muhdiyanto and Muji (2018) finding that there is a significant relationship between role ambiguity on work family conflict. Agres and Ahyar (2018) state that the results of the partial correlation analysis show that role ambiguity is positively correlated with work family conflict. Nurul and Nazaruddin (2016) state that the role ambiguity variable has a positive influence on work family conflict. Jasmani et al. (2015) stated the role of ambiguity had a positive effect on work family conflict.

Based on the results of the analysis shows that role ambiguity has a positive and significant effect on work overload for employees at PT Karya Trustindo Utama Denpasar. This means that the higher the level of role ambiguity experienced by employees, the more work overload is felt by employees. Based on this, the role ambiguity hypothesis has a positive effect on work overload.

This result is supported by research by Atika et al. (2016) found that there was a significant relationship between role ambiguity and work overload. Jasmani and Abdul (2015) stated that the results of the partial correlation analysis showed that role ambiguity was positively correlated with work overload. Sarah et al. (2015) states that the role ambiguity variable has a positive effect on work overload. Muhdiyanto (2018) states that the results of the analysis show that role ambiguity has a positive effect on work overload.

Based on the results of the analysis shows that work family conflict has a positive and significant effect on employee turnover intention at PT Karya Trustindo Utama Denpasar. This means that the more frequent work family conflicts experienced by employees will increase the turnover intention. Based on this, the work family conflict hypothesis has a positive effect on turnover intention.

These results are consistent with research conducted by Jendra and Riana (2015) found that there is a significant relationship between work family conflict and turnover intention. Nurul and Nisa (2016) stated that the results of the t-sobel analysis showed that work family conflict was positively correlated with turnover intention. Veliana et al. (2017) states that work family conflict has a positive effect on turnover intention on employees. Rahmat et al. (2016) in his research proved that work family conflict has a positive effect on turnover intention.

Based on the results of the analysis shows that work overload has a positive and significant effect on employee turnover intention at PT Karya Trustindo Utama Denpasar. This means that the more frequent work overload experienced by employees will make the turnover intention increase. Based on this, the work overload hypothesis has a positive effect on turnover intention.

These results are consistent with research conducted by Nurul and Nisa (2016) finding that there is a significant relationship between work overload and turnover intention. Jasmani and Abdul (2015) stated that the results of the partial correlation analysis showed that work overload was positively correlated with turnover intention. Jendra and Riana (2015) stated 
that work overload has a positive effect on turnover intention. Veliana and Jesslyn (2017) stated the work overload variable has a positive effect on turnover intention.

Based on the results of the analysis shows that work family conflict mediates the influence of role stress and role ambiguity on employee turnover intention at PT Karya Trustindo Utama Denpasar. This means that the more frequent work family conflicts experienced by employees will increase the occurrence of role stress and role ambiguity experienced by employees so that the stronger the desire of employees to make turnover intentions. Based on this, the work family conflict hypothesis mediates the role of stress and the role of ambiguity towards employee turnover intentions.

This result is in accordance with research conducted by Jendra and Riana (2015) describing work family conflict as a problem experienced by employees in the family. This causes the occurrence of role stress and role ambiguity which causes high levels of employee turnover intention. This study is further strengthened by a study conducted by Jasmani and Abdul (2015) stating work family conflict can mediate the influence of role stress and role ambiguity on employee turnover intention. Nurul and Nazaruddin (2016) work family conflict mediates the influence of role stress and role ambiguity which causes high levels of employee turnover intention. Sarah et al. (2015) work family conflict is able to mediate the influence of role stress and role ambiguity on employee turnover intention.

Based on the results of the analysis shows that work overload mediates the influence of role stress and role ambiguity on employee turnover intention at PT Karya Trustindo Utama Denpasar. This means that the more frequent work overload experienced by employees will increase the occurrence of role stress and role ambiguity experienced by employees so that the stronger the desire of employees to make a turnover intention. Based on this, the work overload hypothesis mediates role stress and role ambiguity on employee turnover intention.

These results are in accordance with research conducted by Nurul and Nisa (2016) describing work overload as excessive workload plays a role in determining stress and role ambiguity experienced by employees, causing high employee turnover intention. This statement is reinforced by a study conducted by Sarah et al. (2015) states work overload is able to mediate the influence of role stress and role ambiguity on employee turnover intention. Muhdiyanto and Muji (2018) work overload is able to mediate the influence of role stress and role ambiguity on employee turnover intention. Jendra and Riana (2015) prove in their research that work overload mediates the influence of role stress and role ambiguity on employee turnover intention.

\section{CONCLUSION AND SUGGESTIONS}

Based on the previous discussion, the conclusion of this study is that role stress has a positive and significant influence on turnover intention. This shows that the higher the role stress felt by employees, the stronger the desire of employees to make a turnover intention at PT Karya Trustindo Utama Denpasar. Role stress has a positive and significant effect on work family conflict. This shows that the higher the role stress felt by employees, the more frequent work family conflicts experienced by employees at PT Karya Trustindo Utama Denpasar. Role stress has a positive and significant effect on work overload. This shows that the higher the role stress felt by employees, the more often employees feel work overload at PT Karya Trustindo Utama Denpasar.

Role ambiguity has a positive and significant effect on turnover intention. This shows that the higher the role ambiguity felt by employees, the stronger the desire of employees to make a turnover intention at PT Karya Trustindo Utama Denpasar. Role ambiguity has a positive and significant effect on work family conflict. This shows that the higher the role ambiguity felt by employees, the more frequent work family conflicts experienced by employees at PT Karya Trustindo Utama Denpasar. Role ambiguity has a positive and significant effect on work overload. This shows that the higher the role ambiguity felt by employees, the more frequent work overload experienced by employees at PT Karya Trustindo Utama Denpasar. Work family conflict has a positive and significant influence on 
turnover intention. This shows that the more frequent work family conflicts experienced by employees, the stronger the desire of employees to make a turnover intention at PT Karya Trustindo Utama Denpasar.

Work overload has a positive and significant effect on turnover intention. This shows that the more frequent overload experienced by employees, the stronger the desire of employees to make a turnover intention at PT Karya Trustindo Utama Denpasar. Work family conflict has a significant positive effect as a variable that is able to mediate role stress and role ambiguity on turnover intention. This shows that work family conflict can be a variable of full mediation in the relationship of role stress and role ambiguity to turnover intention at PT Karya Trustindo Utama Denpasar. Work overload has a significant positive effect as a variable capable of mediating role stress and role ambiguity on turnover intention. This shows that work overload is able to be a variable of full mediation in the relationship of role stress and role ambiguity to turnover intention at PT Karya Trustindo Utama Denpasar.

\section{REFERENCES}

1. Abedallah, Aaron Cohen Mohamed. (2015). The mediating role of burnout on the relationship ofemotional intelligence and self-efficacy with OCB and performance, Journal Management Research Review, 38 (1): 2-28.

2. Ariana., Jendra., dan Riana, I Gede. (2015). Pengaruh Work Family Conflict, Keterlibatan Kerja dan Stres Kerja terhadap Kepuasan Kerja Karyawan, Jurnal Manajemen Unud. 5 (7): 4630-4659.

3. Abbasi, T.F. (2015). Impact of Stresson Work Overload, Job Satisfaction, and Turnover Intentions with Moderating Role of Islamic Work Ethics, International Journal of Management Studies and Economic Systems (MSES), 2 (1): 27-37.

4. Asra, Eka Mulyani. (2014). Hubungan antara work-family conflict dengan prestasi kerja pada perawat wanita. Studi makalah Ekonomi. h:15-26.

5. Febrianty. (2012). Pengaruh role conflict, role ambiguity and work-family conflict terhadap komitmen organisasional (Studi Pada KAP di Sumatera Bagian Selatan), Jurnal Ekonomi dan Informasi Akuntansi, 2 (3): 315-339.

6. Fajriani, Arie., Dovi Septiari. (2015). Pengaruh Beban Pekerjaan terhadap Kinerja Karyawan: Efek Mediasi Burnout, Jurnal Manajemen dan Kewirauhsaan. 1 (2): 30-59.

7. Hatta, Atika Jauharia., Zaki Baridwan., Gudono., Supriyadi. (2016). Dampak Role Conflict, Role Ambiguity, dan Role Overload Terhadap Judgment Auditor, Jurnal Manajemen dan Akuntansi, 9 (11): 1-20.

8. Handoko T. Hani. (2014). Manajemen Personalia dan Sumber Daya Manusia. Edisi 2, Yogyakarta: BPFE UGM.

9. Harnida, Hanna. (2015). Hubungan Efikasi Diri Dan Dukungan Sosial Dengan Burnout Pada Perawat, Jurnal Psikologi Indonesia, 4 (1): 31-43.

10. Jamadin, Nurnazirah., Samsiah Mohamad., Zurwina Syarkawi and Fauziah Noordin. (2015). Work - Family Conflict and Stress: Evidence from Malaysia, Journal of Economics, Business and Management, 3 (2): 309-312.

11. Kreitner, Robert., dan Kinicki. (2008). Organizational Behavior. $8^{\text {th }}$ Edition. Boston: McGraw-Hill.

12. Luthans, Fred. (2011). Perilaku Organisasi, Edisi kesepuluh. Andi Offset.

13. Laeeque, Syed Harris. (2014). Role of Work-Family Conflict in Job Burnout: Support from the Banking Sector of Pakistan, International Letters of Social and Humanistic Sciences Online, 40 (1): 1-12.

14. Munda, Agres Oktavia., Ahyar Yuniawan. (2018). PengaruhWork Family Conflict dan Ambiguitas Peran Terhadap Intention to Quit dengan Stress Kerja Sebagai Variabel Intervening (Studi Pada Hotel Grand Edge Semarang), Diponegoro Journal of Manajement. 6 (2): 1-12.

15. Muhdiyanto, Muji Mranani. (2018). Peran Work Family Conflict dan Role Ambiguity pada Turnover Intentions: Burnout sebagai Intervening, Jurnal Manajemen Teknologi, 17 (1): 27-39. 
16. Moekijat. (2010). Manajemen Sumber Daya Manusia. Bandung: Mandar Maju.

17. Nasution, Muhammad Irfan. (2017). Pengaruh Stres Kerja, Kepuasan Kerja Dan Komitmen Organisasi Terhadap Turnover IntentionMedical Representative. Jurnal IImiah Manajemen. 7 (3): 407-428.

18. Nisa, Nurul Hidayatin., Nazaruddin Malik. (2016). Pengaruh Work Overload dan Work Family Conflict Terhadap Turnover intention yang dimediasi oleh Work Exhaustion, Jurnal Ekonomi Bisnis, 7 (1): 67-76.

19. Pradana, Andika (2015). Role of work overload toward turnover intention among newly hired public accountants, International Journal of Economic. 4 (3): 1-17.

20. Puspitasari, Dita Ayu., dan Muryantinah Mulyo Handayani. (2014). Hubungan Tingkat Self-Efficacy Guru dengan Tingkat Burnout pada Guru Sekolah Inklusif di Surabaya. Jurnal Psikologi dan Pendidikan Pengembangan. 3 (1): 59-68.

21. Purbaningrat, I Putu Melati (2015). Pengaruh beban kerja terhadap kepuasan kerja dengan stres kerja sebagai variabel mediasi, Jurnal Manajemen Unud, 4 (5): 1149-1165.

22. Qaiser, Sarah., Amir Gulzar, Waqar Hussain and Hassan Shabbir. (2015). Influence of Work Overload, Work-Family Conflicts and Negative Affectivity on Job Embeddedness and Emotional Exhaustion: The Moderating Role of Coworker Support (Case of Health Management), Journal of Scientific Research \& Reports, 7 (1): 75-85.

23. Rivai, Veithzal. (2006). Kepemimpinan dan Perilaku Organisasi. Jakarta: PT. Raja Grapindo Persada.

24. Robbins, Stephen P. (2014). Perilaku Organisasi. Edisi kesepuluh. Jakarta: PT Indeks Kelompok, Gramedia.

25. Robbins, S.P. (2015). Perilaku Organisasi, Edisi Kedua belas, Jakarta: Salemba Empat.

26. Selvarajan, Rajan., Barjinder Singh, Peggy A. Cloninger. (2016). Role of personality and affect on the social support and work family conflict relationship, Journal of Vocational Behavior, 9 (4): 39-56.

27. Sabuhari, Rahmat., Marwan Man Soleman., Zulkifly. (2016). Pengaruh Stress Kerja Terhadap Work Family Conflict (Studi Kasus Pada Ibu Yang Bekerja sebagai Guru di Kota Ternate), Jurnal Penelitian Humano, 7 (2): 113-125.

28. Santoso, Singgih. (2016). Statistik Non Parametrik Konsep dan Aplikasi dengan SPSS. Jakarta: PT. Elex Media Komputindo.

29. Sudarmawan, Putu Shaini Kusuma. (2017). Pengaruh Role Ambiguity pada Turnover Intentions Auditor Dengan Komitmen Afektif sebagai Variabel Pemoderasi (Studi Empiris pada KAP di Provinsi Bali), Jurnal Manajemen dan Akuntansi, 3 (2): 7-19.

30. Sugiyono. (2014). Metode Penelitian Bisnis. Bandung: CV Alfabeta.

31. Sutanto, Veliana., Jesslyn Angelia Mogi. (2017). Analisis Pengaruh Stress Kerja Terhadap Work Family Conflict dan Kinerja Karyawan di Restoran The Duck King Imperial Chef Galaxy Mall Surabaya, Jurnal Ekonomi dan Bisnis, 5 (1): 377-391.

32. Talachi, Rahil Kazemi., and Mohammad Bagher Gorji. (2015). Evaluating The Relationship Between Job Burnout And Organizational Citizenship Behavior: A Study of Industry, Mine And Trade Organization Employees, Arabian Journal of Business and Management Review, 2 (8):50-61.

33. Tohardi (2007). Manajemen Sumber Daya Manusia. Bandung: CV. Mandar Maju.

34. Villiers, Japie R. de., Marius W. Stander. (2011). Psychological Empowerment, Work Engagement and Turnover Intention: The Role of Leader Relations and Role Clarity in a Financial Institution, Journal of Psychology in Africa, 21(3):405-412.

35. Xiaoming, Yang., Ben-Jiang Ma, Chunchih lisa Chang and Chich-Jen Shieh. (2015). Effects of Workload on Burnout and Turnover Intention of Medical Staff: A Study, International Journal Ethno Med, 8 (3):229-237.

36. Yunus, Jasmani Binti Mohd (2015). Work Overload, Role Ambiguity and Role Boundary and its Effect on Burnout among Nurses of Public Hospitals in Malaysia, International Journal of Research in Humanities and Social Studies, 2 (10): 18-25.

37. Ziaei, Mansour., Hamed Yarmohammad, Meisam Moradi dan Mohammad Khandan. (2015). Level of Workload and Its Relationship with Job Burnout among Administrative Staff, International Journal of Occupational Hygiene, 6 (3): 53- 60. 